\title{
Early growth of Scots pine, European larch and common oak at the young age on post-fire area located in the Sława Śląska Forest District (SW Poland)
}

\author{
"Piotr Robakowski, " Piotr Balicki, "* Maciej Lukaszewski, " ${ }^{* * *}$ Marek Szczerba \\ "Poznań University of Life Sciences, Department of Forest Sites and Ecology, Chair of Ecological Foundations \\ of Silviculture, Wojska Polskiego 71E, 60-625 Poznań, Poland, e-mail: pierrot@up.poznan.pl \\ ${ }^{* *}$ Forest District Sława Śląska, Franciszka Niewidziajły 1A, 67-410 Sława, Poland \\ ${ }^{* * *}$ Forest District Choszczno, I Armii Wojska Polskiego 2, 73-200 Choszczno, Poland
}

\begin{abstract}
The long-term forecasts predict that global warming will increase frequency and area of forest fires. Apart from economic losses resulting from a reduction of wood volume and annual increments of trees, the post-fire areas requiring the reforestation are enlarging considerably.

The present study aimed at the comparison of growth parameters of Scots pine, European larch and common oak seedlings growing on post-fire forest area with those growing in the control forest site established after clear cutting which was not enveloped by fire. We hypothesized that differences in growth traits of seedlings growing on post-fire area or in the control would depend on the species-specific ecological requirements. Among three study species Scots pine was selected to be the most suitable for planting on burnt area taking into account its growth traits and reforestation success.

Scots pine and European larch seedlings showed a greater thickness at root collar and pine had also a greater height on burnt area than in the control. Common oak responded inversely, it grew better in the control conditions compared with the burnt area. The pine grade of slenderness was similar in both treatments. Larch and oak reduced their grade of slenderness growing on post-fire area. Our results supported the hypothesis that the responses of the study trees to the burnt area conditions were determined by the species-dependent traits. The post-fire environment was the most favourable for light-demanding, pioneer pine and larch, but it was disadvantageous for late-successional, more conservative oak. Scots pine together with European larch are recommended to be planted on the burnt area to restore relatively fast the forest ecosystem. At the beginning of reforestation these species can play a role of pioneer crop and later will be able to become the dominant species together with less flammable broadleaved trees in the converted stands.
\end{abstract}

Key words: artificial regeneration, burnt area, forest fire, forest restoration, Larix decidua, Pinus sylvestris, Quercus robur.

\section{Introduction}

The long-term forecasts suggest that the frequency and area of forest fires have increased due to global warming. The high temperatures enhance a rate of evapotranspiration which increases frequency and permanence of drought, especially when it is associated with a reduction of precipitation (IPCC 2001, 2014). Such climatic conditions have been favourable for an increase in number and area of forest fires. Every year, in Europe, around 45000 wildfires occur and the burnt area occupies 0.5 million hectares (Moreira et al. 2012). Forest fires are of great ecological importance due to: (1) death of plants and animals including endemic and other rare species endangered by extinction; (2) their role in global warming - burning of wood biomass is a significant source of $\mathrm{CO}_{2}$; (3) changes in water, carbon and nitrogen cycles which affect functioning of the forest ecosystem; (4) enhancement of soil erosion and changes in carbon sequestration in forest, etc. On the other side, in some forests ecosystems fires play 
a positive role as they accelerate mineralization of organic matter and seeds' germination. Forest fires affect nutrient cycling, physical, chemical and biological properties of soils. Combustion of litter and soil organic matter increases availability of some nutrients, but others are volatilized (DeBano 1990). Fire is not only destructive, but also it is a natural part of many ecosystems. For some tree species e.g. Pinus banksiana Lamb., Pinus contorta var. latifolia Engelm., Pinus halepensis Mill. high temperature during fire is needed for the opening of their serotinous cones (Johnson \& Gustell 1993; Goubitz et al. 2003). However, Scots pine reached its maximum germination rates at relatively low temperatures $\left(70^{\circ} \mathrm{C}-90^{\circ} \mathrm{C}\right.$ ) (Nuñez et al. 2003). Fires cause also considerable economic losses such as wood depreciation, reduction of annual increments, lowering of wood prices and costs related to fire prevention and suppression (Moreira et al. 2012).

Poland is characterised by medium forest fire risk compared with the other European countries. However, there are a high number of forest fires in a relatively small area. Catastrophic fires may occasionally happen as it took place in 1992 (Ubysz et al. 2010; Piwnicki et al. 2013). In Poland, a higher number of forest fires have been observed in nineties of the $20^{\text {th }}$ century together with the increased air temperatures (Polna 2005). Forest fires occur the most frequently from March to September with two maxima in early spring from April to May and during summer drought from July to August (Polna 2005). It seems that global warming resulting in the increases of global temperatures and also in a shorter period of snow cover contributes to an increase in number of forest fires particularly in spring and autumn, although the data from a longer period are needed to confirm this observation. The main reasons of forest fires in Poland are: 1 - arsons, 2 - human activity, for example burning dry meadows is a plague in spring and can induce forest fires, 3 - meteorological conditions i.e. low litter humidity $(\leq 12 \%)$, high air temperature $\left(\geq 24^{\circ} \mathrm{C}\right)$, low air humidity $(\leq 40 \%)$, lack of precipitation, low cloudiness, 4 - species composition and age structure of stands (Piwnicki \& Szczygieł 2013; Piwnicki et al. 2013). Scots pine is a dominant species ( $\sim 69 \%$ of the total forest area) in lowland and Norway spruce in the montane forests both creating monospecific coniferous stands which are more sensitive to fire compared with mixed or deciduous broadleaved forests (Szczygieł et al. 2009; Report about the State Forests in Poland 2013). Forest fires occur frequently at the young stage of stand development: at the thicket and small polewood stage (Karlikowski et al. 1997). Therefore, it can be expected that the number of fires will increase together with the greater area of forested post-agricultural lands (Report about the State Forests in Poland 2013).

Depending on water conditions of the site, the post-fire area can dry due to an increase in evapotranspiration or contrary, if there is a high ground water level and precipi- tation, soil may become more humid and even boggy as there is no transpiration from crowns of trees. The postfire soil may become temporarily impervious to water increasing the amount of water runoff. After a forest fire the secondary succession of plants including forest tree species can begin through germination of seeds conserved in soil seed bank, brought by wind or animals and reproduction with vegetative organs (Dobrowolska 2008). However, the processes of succession up to the forest restoration take long time. Therefore, post-fire area of economic forests should be artificially regenerated as fast as possible to reduce soil erosion and restore forest ecosystem functioning along with the wood production. The key problem is to establish a species composition of trees' plantation on burnt area. The selected species should be able to cope with unfavourable growth conditions such as high temperature amplitudes, high irradiance strong wind and low soil nitrogen content in the post-fire environment.

The main aim of the present study was to compare parameters of early growth of Scots pine, European larch and common oak with regard to use the species in restoration of post-fire area in Poland. We hypothesized that growth responses of seedlings to post-fire site conditions will be determined by the species-specific ecological requirements.

\section{Study site}

The experimental plots were located at the Forest District "Sława Śląska", in west- southern Poland. The Forest District is situated in "Wielkopolsko-Pomorski" Region, "Pojezierze Lubuskie" Province, "Ziemia Lubuska" District, "Plain Nowotomysko-Kargowska" District, "Lowland Wielkopolsko-Kujawska" Province, "Pojezierze Wielkopolskie" District (Trampler et al. 1990).

The plots were randomly distributed in the subcompartment: 299.d.01 (51 ${ }^{\circ} 47^{\prime} 23^{\prime \prime} \mathrm{N}$; $59^{\circ} 03^{\prime} 04^{\prime \prime}$ and 299.a.00 $\left(51^{\circ} 47^{\prime} 27^{\prime \prime} \mathrm{N}\right.$; 59 $\left.12^{\circ} 09^{\prime \prime} \mathrm{E}\right)$ (post-fire area), and on a post clear cutting area in 288.1.00 (51 $47^{\circ} 19^{\prime \prime} \mathrm{N}$; 58 $\left.14^{\circ} 03^{\prime \prime} \mathrm{E}\right)$ and 263.f.01 (51 $47^{\prime} 58^{\prime \prime} \mathrm{N}$; 59 46'04' E) (control). The distance between the plots was around $30-40 \mathrm{~m}$. The relief was lowland with a flat terrain on each plot.

On the territory of the Forest District "Sława Śląska" the prevailing site is the fresh mixed broadleaved forest. The experimental plots on post-fire area and in the control were situated at the site of the fresh mixed broadleaved forest with the brown podzolic soil in both treatments (Brunic Arenosol according to WRB 2006; Marcinek et al. 2011). The sandy gravel soils were enriched with a small loam fraction. At this Forest District five economically important tree species occur in their natural range: Pinus sylvestris L., Fraxinus excelsior L., Quercus petraea Mattuschka (Liebl.), Quercus robur L. and Alnus glutinosa Gaertn. (Forest Management Plan 2006). 
Table 1. The meteorological parameters characterising the local climate of the Forest District "Sława Śląska"

\begin{tabular}{|l|c|}
\hline \multicolumn{1}{|c|}{ Meteorological parameter } & Values \\
\hline Mean annual temperature $\left({ }^{\circ} \mathrm{C}\right)$ & 8.7 \\
\hline Mean temperature of January $\left({ }^{\circ} \mathrm{C}\right)$ & -0.6 \\
\hline Mean temperature of July $\left({ }^{\circ} \mathrm{C}\right)$ & 18.4 \\
\hline Mean annual sum of precipitations $(\mathrm{mm})$ & 526 \\
\hline Mean precipitations sum of vegetative season $(\mathrm{mm})$ & 322 \\
\hline Period of vegetative season (days) & $225-240$ \\
\hline Phenological beginning of spring & 29 March -25 April \\
\hline Phenological beginning of autumn & 25 September -15 October \\
\hline
\end{tabular}

The climate of the Forest District "Sława Śląska" is moderate. It has been formed by the climate of the Great Valleys Region and in the western part by the climate of piedmont lowlands and valleys. The main climatic characteristics of the Forest District are listed in Table 1 (Forest Management Plan 2006). When compared with the other regions of Poland, the vegetative season at the study site was relatively long, mean temperatures were high and the annual precipitations lower than the country mean sum. These meteorological conditions may contribute to a frequent occurrence of forest fires.

\section{Material and methods}

\subsection{Experimental design}

The fire which took place in July 2006 was one of the biggest in the history of the Forest District "Sława Śląska" and occurred on 21.04 ha of forest area and around 20 ha of meadows. The forest fire was classified as the total fire of stand. Not only trees, but also plants of forest cover and litter were burnt.

For $P$. sylvestris and $Q$. robur five 0.01 - ha circular experimental plots $(\mathrm{r}=5.64 \mathrm{~m})$ were established in each of both treatments: on the burnt area and in the control. For L. decidua three plots were in each treatment. The central tree and border of a plot were marked with a paint. The plots were regarded as the true repetitions.

\subsection{Material}

The plant material was originated from the local nursery. Before planting, the soil was prepared with the mean ploughing in all compartments. Bare-root, one-year-old seedlings of Pinus sylvestris and Quercus robur and twoyear-old seedlings of Larix decidua were planted on the burnt area and in the control in 2008 (oak) and 2009 (pine and larch). When the measurements were conducted $P$. sylvestris and $Q$. robur were six-year-old and L. decidua was seven-year-old. There were no weeding or thinning before measurements of growth and the competitive impacts of weeds on seedlings' growth were similar for all plots. The plantations of $Q$. robur and L. decidua were fenced against damages caused by game. The pine plantations were not fenced as damages by game were not significant. The study seedlings grew in the similar site conditions and to the same extent they were threatened by the late frosts. For $P$. sylvestris 378 and 315, for L. decidua 53 and 39, and for $Q$. robur 193 and 174 seedlings were measured in the control and on post-fire area, respectively.

Before growth measurements, survival of seedlings was assessed by counting dead individuals and calculating a percentage of living trees. The survival on post-fire area was 93\% (299.d.01) and $85 \%$ (299.d.01), and in the control $85 \%$. Health condition of saplings was estimated as good or very good taking into account different damages caused by game, pathogenic fungi or insects.

$P$. sylvestris is a fast growing conifer which has the typical traits of a pioneer species. It has a high ecological plasticity and high tolerance to stressors such as: high light, drought, low or high temperatures or deficit of nutrients (Czerwiński, Przybylski 1993; Forestry Compendium 2005). It is characterised by high ecological plasticity which is reflected in the large area of its natural geographical range. In Poland, it can grow in dry habitat being a component of Cladonio-Pinetum, but also in moist or even boggy habitats of Vaccinio uliginosi-Pinetum (Matuszkiewicz 2001).

L. decidua Mill. is a deciduous conifer characterised by even more dynamic growth than pine. It is native to the Alps, mountains of central Europe and there are also lowland populations in northern Poland and southern Lithuania. In contrast to $P$. sylvestris, this species grows well in Polish mountains at mid and high elevations (Boratyński 1986). It is also a pioneer, light-requiring, tolerant to low temperature, but not tolerant to drought and waterlogging (Forestry Compendium 2005). L. decidua has lower ecological plasticity than $P$. sylvestris. 
Q. robur is a deciduous broadleaved tree. It is moderately shade tolerant at the young age. Seedlings of this late-successional tree grow slowly compared with the pioneer species, but faster than those of $Q$. petraea. It is sensitive to a decrease in ground water level, late frosts, summer drought and deficit of nutrients in soil. Generally, the species has the conservative ecological requirements (Modrzyński et al. 2006).

\subsection{Methods}

\subsubsection{Growth measurements}

The measurements of height and thickness at root collar of all seedlings were conducted before the bud opening, in February and March 2014. The height of seedling was measured with accuracy of $5 \mathrm{~mm}$ using a ruler and thickness with accuracy of $1 \mathrm{~mm}$ with an electronic calliper. Then, the grade of slenderness defined as a ratio of height to thickness at root collar $(\mathrm{h} / \mathrm{d})$ was calculated.

\subsubsection{Data analysis}

Before applying the analysis of variance, the data were tested for normality and homogeneity of variance using the Shapiro-Wilk and Levene's test, respectively. The effects of the treatment ( $\mathrm{T}$ : burnt area, control), the species (S: P. sylvestris, L. decidua, Q. robur) and of the interaction $\mathrm{T} \times \mathrm{S}$ were analysed using the two-way analysis of variance with interaction at the significance level $\alpha=0.05$. When the ANOVA results showed the significant differences, the Tukey's a posteriori test was used to compare the species and the treatments in the given species at $\alpha=0.05$.

The relationship between the height of trees and their thickness at root collar was compared between the treatments for each species, separately, using the linear regression. The equations of regression, coefficient of determination (R2) with probability were given. The linear regression was significant at $\mathrm{P}<0.05$. The ANOVA was conducted with Statistica v. 12.0 (Stat Soft, Tulsa, OK, USA) and linear regression with Sigmaplot v. 12 (Systat Software, Inc.).

\section{Results}

The analysis of variance showed significant differences between the species and between the treatments. The mean values of thickness at root collar (d) were 1.5, 4.1 and $6.0 \mathrm{~cm}$ for $Q$. robur, $P$. sylvestris and L. decidua, respectively $(P<0.001)$. The species were ranged in the same order with respect to the mean height (h): 92, 172 and $337 \mathrm{~cm}(P<0.001)$. The differences between the species for $\mathrm{d}$ and $\mathrm{h}$ were significant in Tukey's test. The grade of

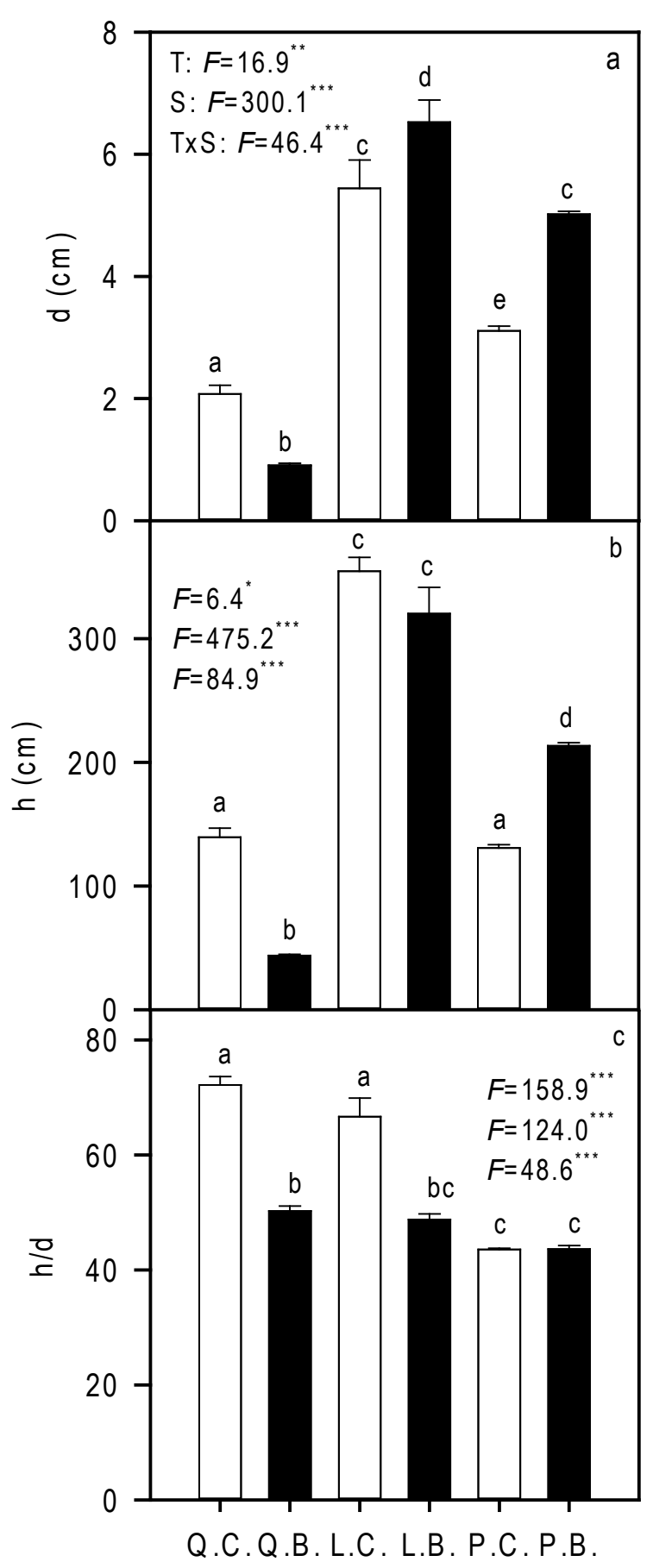

Figure 1. Mean (+SE) values of thickness at root collar (a), height (b) and grade of slenderness (c) of Quercus robur (Q.), Larix decidua (L.) and Pinus sylvestris (P.) growing in the control conditions (C.) or on the burnt area (B). The results of two-way ANOVA for treatment (T), species (S) and interaction (T x S) are shown. $F$ - value of Snedecor's function, $0.05>^{*} P \geq 0.01 ; 0.01>^{* *} P \geq$ $0.001,{ }^{* * *} P<0.001$. The same letters above the columns indicate that the mean values do not differ significantly in Tukey's test at $\alpha<0.05$ 


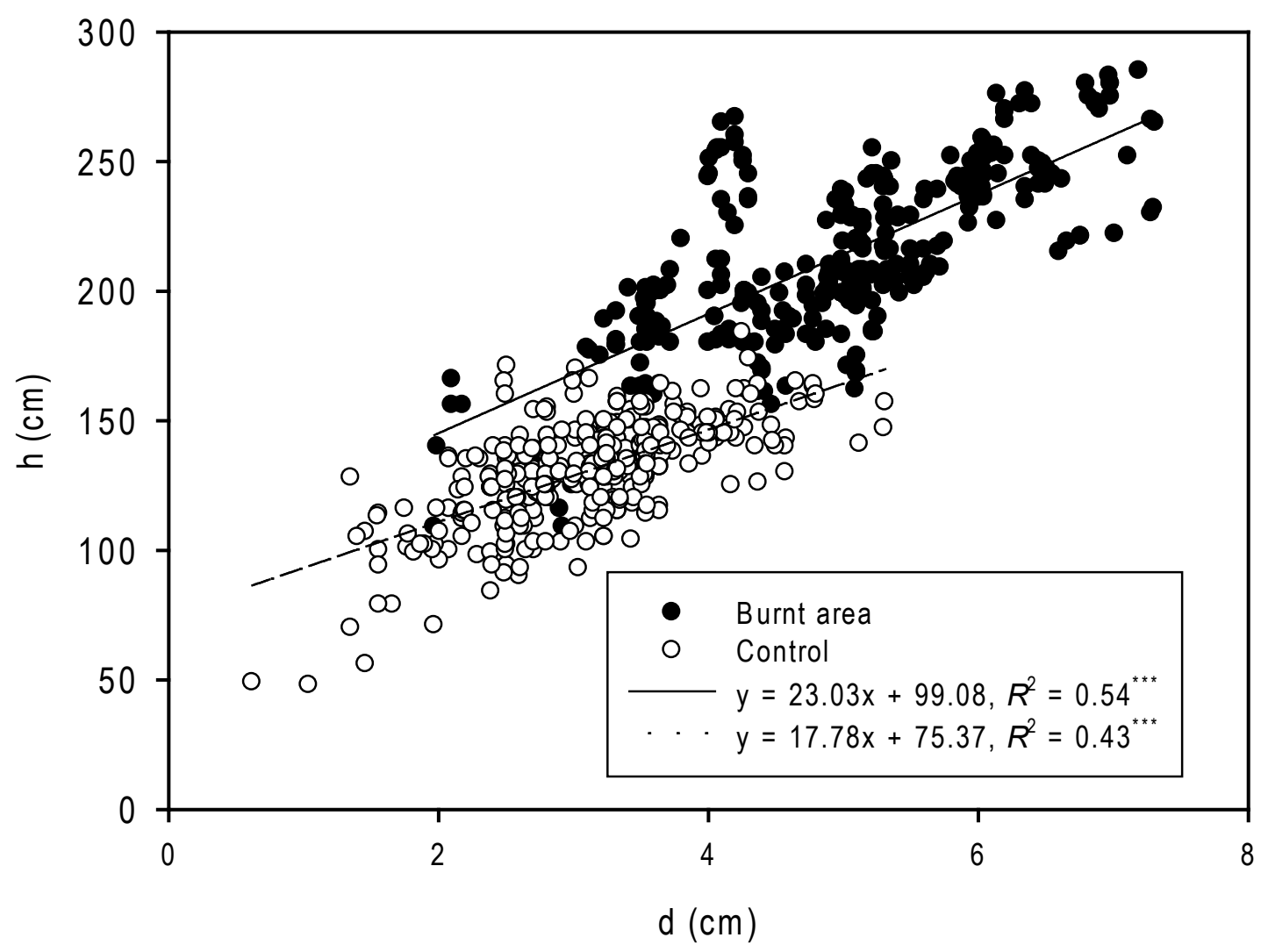

Figure 2. The relationship between the thickness at root collar and height of Pinus sylvestris seedlings growing on the burnt area or in the control. The linear equations together with coefficient of determination $\left(R^{2}\right)$ and probability $(P)$ are given $\left(0.05>^{*} P\right.$ $\left.\geq 0.01 ; 0.01>^{* *} P \geq 0.001 ;{ }^{* * *} P<0.001\right)$

slenderness was lowest for $P$. sylvestris (44) and it differed significantly from $L$. decidua (58) and Q. robur (61) when all seedlings for each species were pooled to calculate the mean values of $h / d$.

The mean values of the growth parameters were compared between the treatments within each species, separately, using the Tukey's test for the interaction $\mathrm{T} \times \mathrm{S}$ (Fig. 1). In seedlings of $Q$. robur all the parameters were higher in the control $(2.1 \mathrm{~cm}, 139 \mathrm{~cm}, 72 ; \mathrm{d}, \mathrm{h}$ and $\mathrm{h} / \mathrm{d}$, respectively) than on burnt area $(0.9 \mathrm{~cm}, 44 \mathrm{~cm}, 50)$ (Figs $1 \mathrm{a}, \mathrm{b}, \mathrm{c})$. In $L$. decidua, the mean value of $\mathrm{d}$ was higher on the burnt area $(6.5 \mathrm{~cm})$ compared with the control $(5.4 \mathrm{~cm})$, but the seedlings did not differ significantly in $\mathrm{h}(320.2$ and $354.5 \mathrm{~cm}$, respectively) and showed the higher $\mathrm{h} / \mathrm{d}$ ratio in the control (67) compared with the burnt area (49) (Figs 1a, b, c). In the post-fire environment, the seedlings of $P$. sylvestris found better growth conditions (5.0,213.3; mean values of $d$ and $h$, respectively) than in the control $(3.1,130.7)$. The pine seedlings acclimatized to one of the treatments did not differ in h/d (44) (Fig. 1c).

The relationship between the $\mathrm{h}$ and $\mathrm{d}$ of seedlings was linear for the species and treatments. Interestingly, in the control there were thinner and smaller seedlings of $P$. syl- vestris than on the burnt area. When $\mathrm{h}$ was compared between the treatments at the same d, it was higher on the burnt area compared with the control. The slope of the regression line for the burnt area was slightly higher (Fig. 2). In $L$. decidua, inversely, at the same d the seedlings were higher in the control (Fig. 3). For Q. robur the ranges of $\mathrm{d}$ and $\mathrm{h}$ values were narrower on the burnt area than in the control. The comparison of the slopes of regression lines indicated that growth of oak seedlings was inhibited by the post-fire conditions (Fig. 4).

\section{Discussion}

Early successional, light requiring $P$. sylvestris and $L$. decidua found suitable conditions for growth in post-fire environment. These pioneer tree species are tolerant to high temperature amplitude, high insolation, wind and unstable water and nutrient content in soil which are typical for a large post-fire area (DeBano 1990; Polna 2005). The results of the present study showed that growth responses of $P$. sylvestris to post-fire site conditions can be positive when compared with trees growing in the control which 


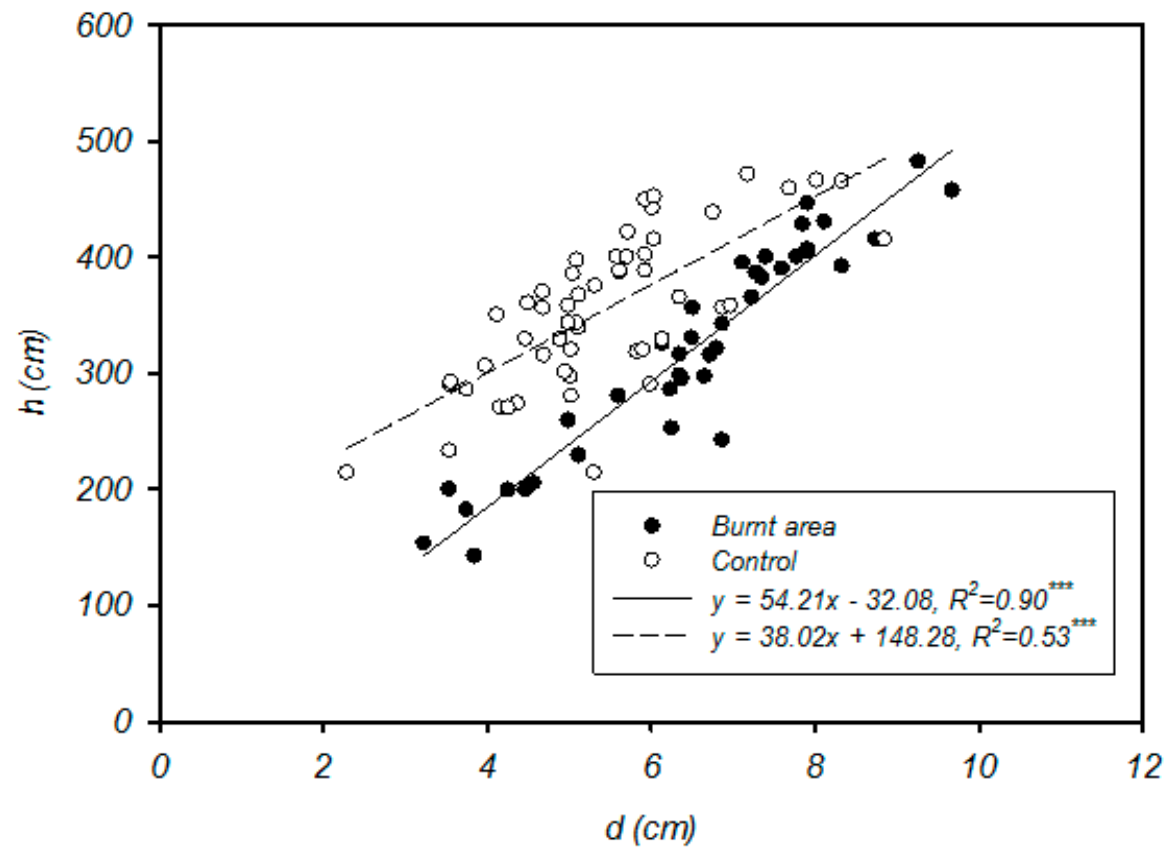

Figure 3. The relationship between the thickness at root collar and height of Larix decidua seedlings growing on the burnt area or in the control. For further explanations see Figure 2

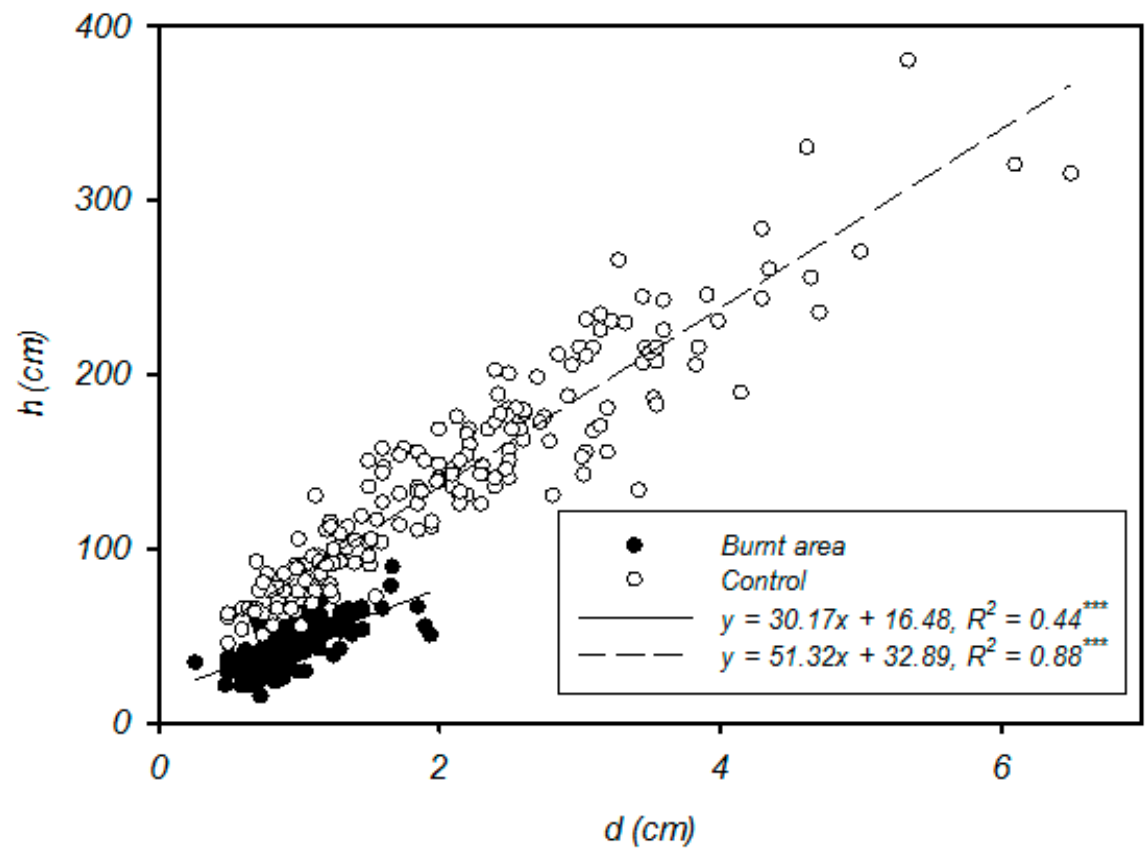

Figure 4. The relationship between the thickness at root collar and height of Quercus petraea seedlings growing on the burnt area or in the control. For further explanations see Figure 2 
was not enveloped by fire. Scots pine had the lowest value of grade of slenderness indicating that the saplings of this species were more tolerant to wind and snow than both other study species. Growth dynamics expressed as the slope of the linear regression between $\mathrm{d}$ and $\mathrm{h}$ were higher, especially for L. decidua in the post-fire environment. In contrast, late successional and shade tolerant at the young age $Q$. robur reduced its $\mathrm{d}$ and $\mathrm{h}$ growing on the burnt area. Its growth dynamics was lower compared with the control.

The results of our study supported the hypothesis that the responses of trees to the post-fire environment would depend on the species ecological requirements. It appeared that for P. sylvestris and L. decidua high insolation and lack of competition with neighbouring weeds in the open post-fire area can compensate to some extent the disadvantages offered by this environment. It is also plausible that the contents of phosphorous, potassium, calcium and magnesium were higher in post-fire soil compared with the typical forest soil (DeBano 1990; Polna 2005). However, these conditions were not suitable for $Q$. robur which is moderately shade tolerant at the young age and is sensitive to high temperature amplitudes, in particular the late frosts, and high insolation (Gross et al. 1996; Oszako 2000). On the burnt area there was not a natural protection of neighbouring plants against these unfavourable for oak climatic factors. Additionally, $Q$. robur is not tolerant to water deficit in soil which could also cause a reduction of its growth on the burnt area (Jaworski 2011). As a result of fire, forty chemical compounds are formed which too high concentration may increase a danger of physiological drought (Polna 2005).

$P$. sylvestris has a large geographical range and occupies different habitats creating numerous ecotypes. It cannot be excluded that if another provenances of pine would have been used in our experiment, the results had been opposite to those given in this study. It exists an intraspecific variability of $P$. sylvestris in response to the post-fire environment, which should be taken into account when pine is used for planting on burnt area (Hawryś et al. 2008). A provenance differentiation can be also expected in other species used for reforestation of the post-fire areas. The other limitation of our conclusions is the young age of the study trees. The ranking of the species established in response to the post-fire conditions may change with the age of trees.

Although L. decidua is a montane species, it is often used as and admixture for reforestation and afforestation of post-agricultural areas (Puchniarski 2000). The present results indicated that this fast-growing pioneer tree is able to cope perfectly with the post-fire environment even outside its natural range of occurrence. In comparison with $P$. sylvestris, this species is more requiring for water and soil conditions, but it is characterised by the highest growth dy- namics and is extremely tolerant to high temperature amplitudes and low temperatures (Forestry Compendium 2005).

In the context of our results the question can be addressed if planting of $Q$. robur and other species showing a reduction of growth under post-fire conditions may provide some advantages, in particular, if it might reduce a risk of fire hazard and future fire severity (Thompson et al. 2007). First, it is not clear if only the post-fire factors diminished growth dynamics of $Q$. robur. We cannot exclude that the soil conditions were not optimal for $Q$. robur and instead of this species $Q$. petraea, which is more drought tolerant, should have been planted (Jaworski 2011). The overarching priority of the reforestation of the burnt area should be to maintain the sustainability and continuity of the functioning of forest ecosystem. Therefore, besides the pioneer species, an admixture of less flammable, broadleaved species should be planted. In our study $Q$. robur showed a low growth and quality on the burnt area, but this species is less flammable and its litter decomposes faster than that of conifers improving soil conditions. The flammability index of oaks is 0.77 , and that of L. decidua and P. sylvestris 1.24 (Szczygieł et al. 2009).

There is evidence that $P$. sylvestris and L. decidua can be recommended to be planted on the post-fire area. This conclusion was also supported by the results of the earlier studies conducted on the other type of site: the fresh coniferous forest (Ceitel et al. 2012). However, the regeneration of the monospecific or mixed pine - larch stands will not reduce a risk of fire in the future forest; both species were classified among the most flammable ones (Szczygieł et al. 2009). Therefore, it would be reasonable to plant them to begin a progressive comeback of forest ecosystem, but at the same time, the stand transformation with the use of less flammable species should be planned. To minimize a danger of forest fire, the stand transformation can begin at the early stage of forest development. As the result, the mixed stands with coniferous and broadleaved deciduous species would be less threatened by fires compared with monospecific, coniferous forests (Szczygieł et al. 2009), although the stand conversion is a long process and technically difficult. The forests being transformed are often damaged by game, thus they have to be fenced. There is a dilemma between the rapid regeneration of forest using only the pioneer coniferous species and reforestation linked with the stand conversion with the less flammable broadleaved tree species. An interesting solution can be a plantation of pine and larch with Alnus incana (L.) Moench which is a less flammable species and, importantly, bacteria living in its roots are able to assimilate nitrogen from the air. This natural soil fertilization with nitrogen stocked in $A$. incana roots can improve growth conditions in post-fire soil with a deficit of nitrogen. The beneficial effect of alder on the size of diameters at breast height of 
pines was already observed at $25 \%$ of participation of this species (Barzdajn et al. 2012).

To diminish the negative effects of fires on forest ecosystems, the rapid regeneration of stands and an enhancement of their tolerance to fire is required. Further studies should concern the use of less flammable broadleaved species for the transformation of post-fire monospecific stands to regenerate the forest ecosystem and reduce a danger of future fire.

\section{Acknowledgments}

We thank two anonymous reviewers for constructive comments.

\section{References}

Barzdajn W., Ceitel J., Korzeniewicz R. \& Kowalkowski W., 2012, Wpływ olszy szarej na wzrost sosny zwyczajnej w warunkach suchego i oligotroficznego siedliska na pożarzysku [Influence of grey alder on Scots pine growth in the dry oligotrophic habitats in a postfire area], Sylwan 156(1): 28-35.

Boratyński A., 1986, Systematyka i geograficzne rozmiesczenie [Taxonomy and geographical distribution], [in:] S. Białobok (ed.), Modrzewie [Larches], PWN, Warsaw.

Ceitel J., Barzdajn W., Zientarski J., Korzeniewicz R., 2012, Sposoby przygotowania gleby po pożarze lasu a przeżywalność i wzrost wybranych gatunków drzew [Methods of soil preparation after forest fire and survivor and growth of the selected tree species], III Konferencja Puszcza Notecka "Człowiek, Las, Drewno", Sieraków, 16-18 października 2012: 234 [in Polish].

Czerwiński A. \& Przybylski T., 1993, Ekologia [Ecology], [in:] S. Białobok, A. Boratyński, W. Bugała (eds.) Biologia sosny zwyczajnej [Biology of Scots pine], Polish Academy of Sciences, Sorus, Poznań-Kórnik: 255-300.

DeBano L. F., 1990, The effect of fire on soil properties, Symposium on Management and Productivity of Western-Montane Forest Soils. Intermountain Research Station, Forest Service, United States Department of Agriculture, Idaho. Boise, ID, April 10-12, 1990, http:// www.fs.fed.us/rm/pubs_int/int_gtr280.pdf

Dobrowolska D., 2008, Odnowienie naturalne na powierzchniach uszkodzonych przez pożar w Nadleśnictwie Rudy Raciborskie [Natural regeneration on postfire area in Rudy Raciborskie Forest District], Leśne Prace Badawcze 69 (3): 255-264.

Forestry Compendium, 2005, Centre for Agriculture and Biosciences International, Larix decidua, [in:] Forest- ry Compendium, Global Edition, CAB International, Wallingford, UK.

Forest Management Plan, 2006, Forest Management Plan of the Forest District Sława Śląska, Warszawa.

Gross K., Homlicher A., Winreich A. \& Wagner E., 1996, Effect of shade on stomatal conductance, net photosynthesis, photochemical efficiency and growth of oak saplings, Annales des Sciences Forestières 53: 279-290.

IPCC, 2001, Climate Change 2001: Impacts, Adaptation, and Vulnerability, J. J. McCarthy, O. F. Canziani, N. A. Leary, D. J. Dokken, K. S. White (eds.), Cambridge University Press, New York.

IPCC, 2014, Climate Change 2014: Impacts, Adaptation, and Vulnerability. Agriculture, Forestry and Other Land Use (AFOLU), P. Smith, M. Bustamante et al., http:// www.report.mitigation2014org/drafts/final-draft-posplenary/ipcc_wg3_ar5_final-draft_postplenary_chapter11.pdf.

Johnson E. A. \& Gustell S. L., 1993, Heat budget and fire behaviour associated with the opening of serotinous cones in two Pinus species, Journal of Vegetation Science 4: 745-750.

Goubitz S., Werger M. J. A. \& Ne'eman G., 2003, Germination response to fire-related factors of seeds from non-serotinous and serotinous cones, Plant Ecology 169: 195-204.

Hawryś Z., Zwoliński J., Kwapis Z. \& Matuszczyk I., 2008, Rozwój różnych pochodzeń sosny zwyczajnej na pożarzysku w Nadleśnictwie Potrzebowice [Development of various Scots pine provenances on burnt area in Potrzebowice forest district], Leśne Prace Badawcze 69 (1): 57-65.

Jaworski A., 2011, Hodowla lasu. Charakterystyka hodowlana drzew leśnych [Silviculture. Silvicultural Characteristics of Forest Trees], PWRiL, Warsaw.

Karlikowski T., Dąbrowska-Zielińska K., Zawiła-Niedźwiedzki T., Gruszczyńska M., Santorski Z., Sakowska H. \& Janowska M., 1997, Wykorzystanie zdjęć satelitarnych NOAA-AVHRR do wspomagania oceny zagrożenia pożarowego lasu [The use of satellite pictures NOAA-AVHRR to support the estimation of forest fire hazard], Prace IBL, ser. A, Nr 829.

Marcinek J., Komisarek J., Bednarek R., Mocek A., Skiba S. \& Wiatrowska K., 2011, Systematyka Gleb Polski [Soil Classification of Poland], Roczniki gleboznawcze LXII(3): 1-193.

Matuszkiewicz J. M., 2001, Zespoły leśne Polski [Forest associations in Poland], PWN, Warszawa.

Modrzyński J., Robakowski P. \& Zientarski J., 2006, Ekologia [Ecology], [in:] W. Bugała (ed.), Dęby [Oaks], Polish Academy of Sciences, Bogucki Wydawnictwo Naukowe, Poznań: 411-474.

Moreira F., Arianoutsou M., Vallejo M. R., de las Heras J., Corona P., Xnthopoulos G., Fernandes P. \& Papa- 
georgiou K., 2012, Setting the scene for post-fire management, [in:] F. Moreira, M. Arianoutsou, P. Corona, J. De les Heras (eds), Post-fire management and restoration of southern European forests, Managing Forests Ecosystems, Springer, Dordrecht, Heidelberg, London, New York.

Nuñez M. R., Felipe Bravo F. \& Calvo L., 2003, Predicting the probability of seed germination in Pinus sylvestris L. and four competitor shrub species after fire, Annals of Forest Sciences 60: 75-81.

Oszako T., 2000, Oak declines in Europe's forests - history, causes and hypothesis, [in:] T. Oszako, C. Delatour (eds), Recent Advances on Oak Health in Europe, IBL, Warsaw: 11-41.

Piwnicki J., Szczygieł R., Klimczak A., 2013, Utrzymanie krajowego systemu informacji o pożarach lasów [Maintenance of the country information system about forest fires]. Report for the Ministry of Environment, Forest Research Institute, http://www.nfosigw.gov.pl/ download/gfx/infosigw/pl/.../858/.../2012-650.pdf

Piwnicki J. \& Szczygieł R., 2013, Poland, [in:] Forest Fires in Europe, Middle East and North Africa 2012, Report EUR 26048 EN, 2013, Joint report of JRC and Directorate-General Environment, Publication Office of European Union, Luxemburg: 45-49.
Polna M., 2005, Zróżnicowanie natężenia pożarów leśnych w Polsce w latach 1990-2003 [Diversity of forest fires intensity in Poland between 1990 and 2003], Acta Scientiarum Polonorum Silvarum Colendarum Ratio et Industria Lignaria 70 (2): 131-141.

Puchniarski T. H., 2000, Zalesienia porolne [Post-agricultural afforestation], PWRiL, Warsaw.

Report about the State Forests in Poland 2013, The State Forests National Forest Holding, Warsaw.

Szczygieł R., Ubysz B., Kwiatkowski M. \& Piwnicki J., 2009, Klasyfikacja zagrożenia pożarowego lasów Polski [Forest fire hazard classification in Poland]. Leśne Prace Badawcze [Forest Research Papers] 70 (2): 131141.

Thompson J. R., Spies T. A. \& Ganio L. A., 2007, Reburn severity in managed and unmanaged vegetation in a large wildfire, Proceedings of National Academy of Sciences 104(25): 10743-10748.

Trampler T., Kliczkowska A., Dmyterko E. \& Sierpińska A., 1990, Regionalizacja przyrodniczo-leśna [Natural-Forest Regionalization], PWRiL, Warszawa.

Ubysz B., Szczygieł R. \& Piwnicki J., 2010, Poland, [in:] Forest Fires in Europe 2009, Joint report of JRC and Directorate-General Environment, Pulication Office of European Union, Luxemburg: 39-43. 



\title{
Water runoff from road surface in mountain forests
}

\author{
Janusz Gołąb \\ Department of Forest Engineering \\ Faculty of Forestry, University of Agriculture in Kraków \\ Al. 29-listopada 46, 31-425 Kraków \\ e-mail: rlgolab@cyf-kr.edu.pl
}

\begin{abstract}
Forest roads are treeless strips of land without any natural cover, appropriately shaped in a longitudinal and transverse direction, along which traffic is possible. Road embankments and surfaces are made of proper materials, with the preservation of technological requirements and particular attention to the density of subbases in the road construction. Surface water runoff occurs on all roads as a result of rainfall, because material density of the surface hinders or blocks the infiltration and the road gradient causes the water movement. Precipitation intensity and ground filtration capacity determine the runoff quantity. In forest areas, the surface runoff basically occurs on road surfaces and timber depots, while outside those sites, it rarely occurs in natural and not devastated areas. The paper presents the results of measurements of the surface-runoff intensity from forest dirt roads along several surveyed sections. Some sections were characterised by a high escarpment of the excavation and cross-cut canal for subsurface runoff. The unit intensity from measurement sessions of various precipitation levels was presented, as well as those from the period of snow cover melting. Measurements were taken every 15 minutes. On the basis of these measurements, simulation calculations of the amount of water were performed assuming the homogeneity of the area, the road network and precipitation characteristics, which can occur in the form of surface runoff on forest roads with similar characteristics, in the area of 100 ha, with the road network density of $15 \mathrm{~m} \cdot \mathrm{ha}^{-1}$ and $25 \mathrm{~m} \cdot \mathrm{ha}^{-1}$, during the precipitation lasting $3 \mathrm{~h}$. These values were referred to the total water quantity from such precipitation and compared with the standard water consumption by an average consumer.
\end{abstract}

Key words: runoff quantity, simulation, forest road network, road trench, slope drainage.

\section{Introduction}

Water, during its circulation in the hydrological cycle, reaches surface area in the form of the precipitation. When limiting the examination to precipitation liquid form, it can be stated that after entering area (land) surface, water either soaks into the ground or remains on its surface. This depends on two factors: ground filtration ability and precipitation intensity. Filtration ability strongly depends on ground structure that is from mutual grain and particle arrangement (Bochenek 2002), but also on condition of ground profile saturation with water from previous precipitation. Natural grounds with stable plant cover, e.g. forest grounds are characterised by relatively high porosity and as a result they can soak high amounts of water coming from precipitation. In the case of anthropogenically compacted soil, the structure and porosity are changed, which also changes conditions of water movement in the ground. Then such situation can take place that not the whole precipitation quantity, which has reached surface area, can be soaked by land (Wemple \& Jones 2003). This excess amount creates surface runoff on sloping surfaces as a result of gravitational force. Differences in filtration capacity in various grounds are provided by Gil (1990, after Słupik 1972): in abandoned agricultural soil $-90 \mathrm{~mm} \cdot \mathrm{min}^{-1}$, in ploughed soil $-1.2 \mathrm{~mm} \cdot \mathrm{min}^{-1}$, which can be compared with filtration capacity in ground surface of a slope road with high quantity of a natural structure: $0.00 \div 0.05 \mathrm{~mm} \cdot \mathrm{min}^{-1}$ (Gołąb et al. 2006). 
Table 1. The quantity of surface runoff in the forest areas of the Tatra Mountains (Midriak 1990)

\begin{tabular}{|c|c|cc|}
\hline Forest area & $\begin{array}{c}\text { Description } \\
\text { (height above sea level, fall, exposition) }\end{array}$ & Quantity of surface runoff \\
\hline Soil without plant cover (on storage area) & $1365 \mathrm{~m}$ above sea level, 18, $\mathrm{SSE}$ & $\begin{array}{c}312023 \\
0.00000099\end{array}$ & $\begin{array}{c}{\left[\mathrm{dm}^{3} \cdot \mathrm{ha}^{-1} \cdot \mathrm{year}^{-1}\right]} \\
{\left[\mathrm{dm}^{3} \cdot \mathrm{m}^{-2} \cdot \mathrm{s}^{-1}\right]}\end{array}$ \\
\hline Young fir tree & $1300 \mathrm{~m}$ above sea level, $8-16^{\circ}, \mathrm{NNE}$ & $\begin{array}{c}29287 \\
0.00000009\end{array}$ & $\begin{array}{c}{\left[\mathrm{dm}^{3} \cdot \mathrm{ha}^{-1} \cdot \mathrm{year}^{-1}\right]} \\
{\left[\mathrm{dm}^{3} \cdot \mathrm{m}^{-2} \cdot \mathrm{s}^{-1}\right]}\end{array}$ \\
\hline Fir forest stand of $100-150$ years old & $1343 \mathrm{~m}$ above sea level, 28, $\mathrm{N}$ & $\begin{array}{c}174823 \\
0.00000055\end{array}$ & $\begin{array}{c}{\left[\mathrm{dm}^{3} \cdot \mathrm{ha}^{-1} \cdot \mathrm{year}^{-1}\right]} \\
{\left[\mathrm{dm}^{3} \cdot \mathrm{m}^{-2} \cdot \mathrm{s}^{-1}\right]}\end{array}$ \\
\hline
\end{tabular}

Surface runoff is rarely observed in forested areas with undevastated, natural soil and plant cover. It is formed only after heavy precipitation on steep slopes covered with soil of low thickness level or in the case of ground saturation as a result of earlier precipitation (Kosturkiewicz \& Szafrański 1983). The quantity of surface runoff observed in the Tatra mountains are provided by Midriak (1990) (Table 1).

Other study, conducted by Słupik (1972), provide information about the quantity of surface runoff measured in the forest: $100 \mathrm{l} \cdot \mathrm{ha}^{-1} \cdot \mathrm{min}^{-1}\left(0.000167 \mathrm{dm}^{3} \cdot \mathrm{m}^{-2} \cdot \mathrm{s}^{-1}\right)$ during heavy precipitation $60-90 \mathrm{~mm}$, lasting for 1-2 hours.

Water in surface runoff omits a very important phase of water circulation in nature, namely the subsurface retention phase (Gołąb 2004), whose result are high stream levels after heavy precipitation and a threat of flood. The next outcomes were low ground water levels and the lack of water for broadly understood consumption. Therefore, the key factor in occurring of the surface runoff is surface area feature, just after precipitation intensity, which can be named as tightness of this surface and its fall. Water flowing in the form of surface runoff from the catchment area, very quickly reaches the stream dehydrating the valley and becomes unavailable for the valley ecosystem. Gradkowski (2011) states that surface runoff in areas, out of a forest or a city, constitute about $20 \%$ of precipitation, whereas it is about $80 \%$ in the city as a result of tightness of area cover.

The areas which have high level of tightness are, inter alia, surfaces of roads, squares, building roofs and rock outcrops with low cracking level. Mentioned infrastructure elements are made with gradients in order to force water flow from external areas, which is the basic condition improving durability and functionality of buildings in our climate. In forest areas, roads, less often squares with the function of timber yards, possibly buildings can be seen among other objects with high level of tightness.

Forest areas must be appropriately made available, so that it will be possible to use them in compliance with the provisions of the forest law (Ustawa o lasach 1991). Apart from the function of protecting waters, soils and air, creating the living environment for a vast number of plants and animals. The forest fulfils also other important functions: it is the place for producing the multi-functional material - wood and many other raw materials, valuable for industry and society; it is a reserved area; the place of work, the place for rest, recreation and education; the place for pursuing sport and active tourism. It also has functions related to state defence. Fulfilling many of these functions by forest is inseparably linked to the possibility of communication that is existence of the forest road network. Roads are treeless strips of land, without natural coverage, appropriately shaped in longitudinal and transverse directions, on which car traffic with particular characteristics is possible. Light traffic with low intensity level can take place on roads with ground surface, however traffic of heavy-load vehicles is possible only on roads equipped with surfaces of high load rating, made of adequate materials and what is important, in compliance with the technical requirements. Surface water flow is created as a result of rainfall on all road surfaces, which have been properly constructed and maintained, but also on these, which have ruts and are eroded (Martinez-Zavala et al. 2008).

The subject of this work is surface runoff created on forest roads in mountainous areas. The objective of this work is to describe the meaning of surface runoff occurring in mountainous forest areas by analysing results of area measurements and simulation calculations for the described area.

Formulated the hypothesis that the density of the road network is significant for the size of surface runoff forming in mountain forest.

\section{Materials and methods}

\subsection{Study area}

The measurements were made in the catchment area of Dupniański Stream in the Silesian Beskid mountains, Forestry Division of Wisła (Fig. 1). The complete characteristics of the catchment area are provided by Suliński (1997), the most important parameters have been provided below.

The catchment area is located in the zone of Carpathian climate, in the river basin of Olza, standard annual precipi- 


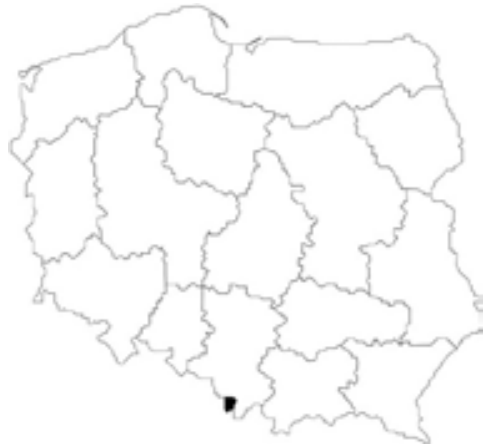

Figure 1. Location of Wisła Forestry Division

tation is $1200 \mathrm{~mm}$, average specific runoff in the long-term is $23 \mathrm{dm}^{3} \cdot \mathrm{s}^{-1} \cdot \mathrm{km}^{-2}$, average annual evapotranspiration is $515 \mathrm{~mm}$, average annual air temperature is $+5.5^{\circ} \mathrm{C}(\mathrm{Kli}-$ maszewski 1972; Stachý 1987). Catchment area is $1.68 \mathrm{~km}^{2}$, area ordinates $492.70 \mathrm{~m} \div 881.90 \mathrm{~m}$ above sea level, density of water network $3.64 \mathrm{~km} \cdot \mathrm{km}^{-2}$ (Czarniecka 1998).

The characteristics of selected sections of a slope road, on which measurements of surface runoff were conducted (Gołąb et al. 2006) is provided in the Table 2.

\subsection{Runoff measurements}

A single measurement section was indicated by installing two water culverts on the road surface. A culvert blocking water supply from the part of the road located above the surveyed section was installed in the upper part of the section, whereas a culvert placed below, collected the whole amount of water running off the surveyed section surface and it was equipped with a measuring container of about $25 \mathrm{dm}^{3}$. Measurement of the quantity of water collected by the measuring culvert was started every 15 minutes and lasted most frequently 5 minutes (with the precision of 1 s.) or the number of seconds was recorded, if the container filled in quicker. Water capacity was recorded with the precision of $0.1 \mathrm{dm}^{3}$. Water culverts were built and installed in the manner providing measurement of the whole runoff without any losses.

Precipitation was measured in two places: directly next to the road, on which runoff measurements were conducted and at the time of their performance, as well as in order to conduct other analyses (also of controlling purposes) at the flow area closing the catchment area. Precipitation at the road was measured every 15 minutes at the time of starting each measurement, however standard daily total quantity was recorded at the closing flow area.

Measurements were started on all sections at the same time and the obtained measurement results made it possible to compare measured values by calculating single runoff intensity - q', (in relation to $1 \mathrm{~m}^{2}$ ).

\subsection{Calculations conducted in the simulation of surface runoff from the network of forest roads}

Knowing the levels of the unit intensity of surface runoff from forest roads, simulation calculations can be conducted on the quantity of water runoff from a larger forest area, characterised by the existing or planned density of the road network. Such simulation is presented below.

Some preliminary assumptions should be made at the beginning of simulation calculations. It was assumed that

Table 2. Description of surveyed sections

\begin{tabular}{|c|c|c|c|c|c|}
\hline \multirow{2}{*}{\multicolumn{2}{|c|}{$\begin{array}{c}\text { Section description } \\
\text { A }\end{array}$}} & \multicolumn{4}{|c|}{ Section } \\
\hline & & $\mathrm{C}$ & $\mathrm{D}$ & $\mathrm{E}$ & \\
\hline \multicolumn{2}{|l|}{ Surface type } & \multicolumn{4}{|c|}{ ground with high amount of natural structure } \\
\hline Section length & {$[\mathrm{m}]$} & 37.10 & 60.40 & 43.95 & 54.10 \\
\hline Average width of carriageway & {$[\mathrm{m}]$} & 2.10 & 2.20 & 2.62 & 2.30 \\
\hline Road surface on a section & {$\left[\mathrm{m}^{2}\right]$} & 77.91 & 132.88 & 115.00 & 124.43 \\
\hline Ground filtration coefficient in the surface & {$\left[\mathrm{cm} \cdot \mathrm{min}^{-1}\right]$} & 0.003 & 0.000 & 0.000 & 0.004 \\
\hline Average section gradient & {$[\%]$} & 1.82 & 8.22 & 9.17 & 8.37 \\
\hline Presence of water effusion from a scarp & $(+),(-)$ & - & + & + & - \\
\hline Average height of a scarp trench & {$[\mathrm{m}]$} & 0.96 & 1.61 & 2.44 & 1.75 \\
\hline Average height of a scarp bank & {$[\mathrm{m}]$} & 0.45 & 0.65 & 0.87 & 0.38 \\
\hline Tree age & [years] & 55 & 50 & 80 & 80 \\
\hline Road cover with tree stand & {$[\%]$} & 70 & 30 & 30 & 40 \\
\hline
\end{tabular}


the conditions in which surface runoff was measured were average conditions in the simulation area. This applies to all area features, forest stand, roads, lands and precipitation. The assumed simulation area was 100 ha and runoff for two various densities of road networks were simulated: 15 and $25 \mathrm{~m} \cdot \mathrm{ha}^{-1}$. These values are from the range of the density of forest roads for the areas in the Carpathians recommended in the literature (Drogi leśne 2006). It was also assumed that the described precipitation cases lasted for 3 hours and simulations were conducted for-each of such periods.

Calculation of the water quantity in the surface runoff was based on the aforementioned measurements of the runoff intensity. For selected measurement sessions (15 September, 9 October and 16 October 2004 with precipitation: $9.8 \mathrm{~mm}, 5.2 \mathrm{~mm}$ and $2.8 \mathrm{~mm}$ and in the previously described session of 21 March 2004 without precipitation, during spring snowmelts), average single intensity was calculated, which was then calculated by the surface of roads (with the assumed average road width of $3 \mathrm{~m}$ ). Calculated quantities of surface runoff were also referred to the precipitation amount on the whole simulated area.

\section{Results}

\subsection{Quantity of surface runoff}

The results of measurements of the surface runoff intensity are presented below (Figs 2-4). They were conducted on selected road sections during three measurement sessions, different from each other in the precipitation level.

\subsection{Simulation of the runoff level from the network of forest roads}

The calculated average values of single intensity of the surface runoff were provided in Table 3 for different road sections and measurement sessions conducted during specific precipitation cases. Average values of single runoff intensities from all sections were also provided in Table 3 as representative values for the whole session and the whole area. These average values represented the basis for further simulation calculations.

Calculated quantities of the water coming from the surface runoff were provided in Table 4; the values are related to the surface of forest roads in the area of 100 ha at defined densities of the road network and assumptions defined in the chapter "Methodology". Moreover, the percentage of this runoff was compared with the general precipitation capacity.

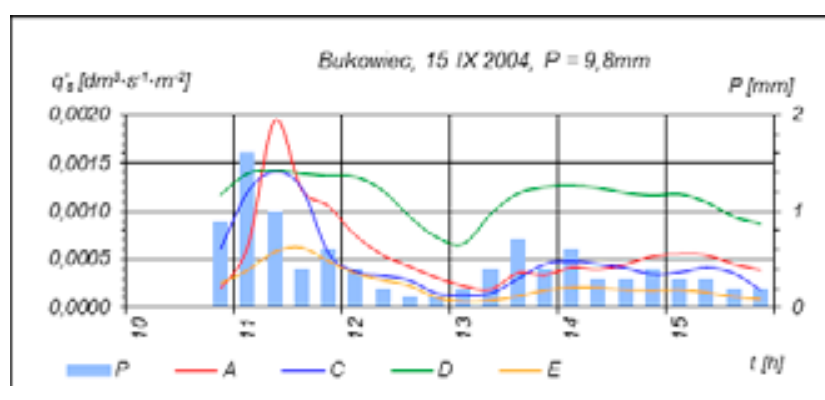

Figure 2. Intensity of surface runoff from sections of forest roads during the period of precipitation of $9.8 \mathrm{~mm}$

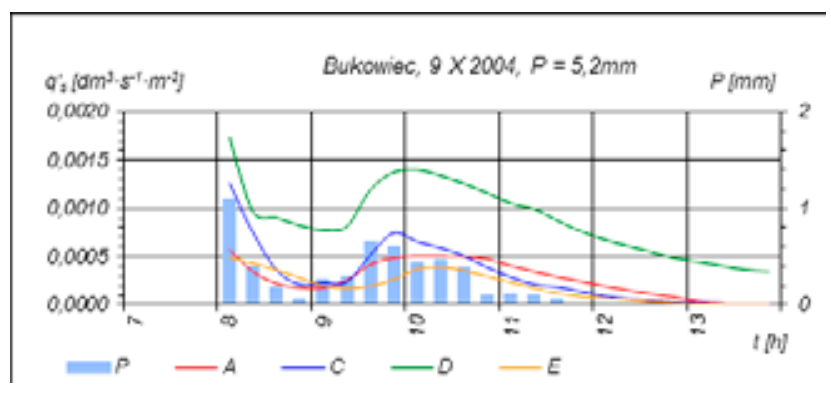

Figure 3. Intensity of surface runoff from sections of forest roads during the period of precipitation of $5.2 \mathrm{~mm}$

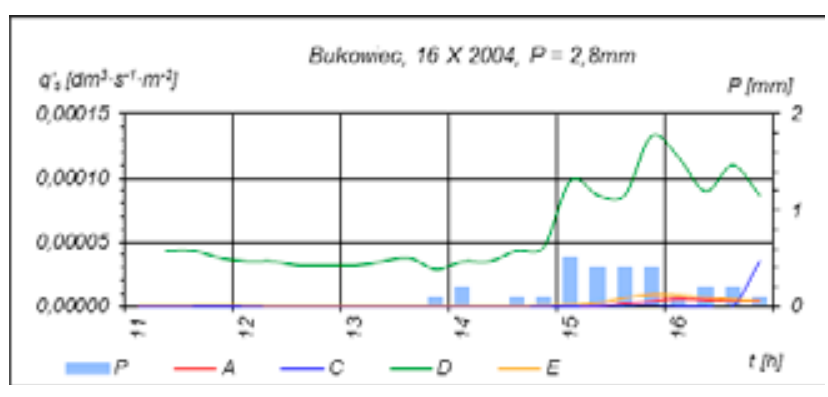

Figure 4. Intensity of surface runoff from sections of forest roads during the period of precipitation of $2.8 \mathrm{~mm}$

\section{Discussion and conclusions}

The data presented on the charts provides actual values of surface runoff of water from forest roads, whereas the applied measuring interval (15 minutes) shows the dynamics of this important ecological problem very well. The Figure 4 shows the starting point in the process of runoff forming at small cumulative precipitation. The interception phase of the initial precipitation through the forest hood was expressly shown as well as the surface of the road itself initial precipitation intensity was at the level between 0.1 $\div 0.2 \cdot 15 \mathrm{~min}^{-1}$ does not cause runoff creation, but only moistens the surface, was expressly provided. Small reaction took place only in the section $\mathrm{D}$, where the scarp 
Table 3. The average single surface runoff intensity from selected sections of forest roads

\begin{tabular}{|c|c|c|c|c|c|}
\hline \multirow{2}{*}{ Precipitation } & \multicolumn{4}{|c|}{ Road section } & \multirow{2}{*}{$\mathrm{q}_{\text {average }}^{\prime}$} \\
\hline & A & $\mathrm{C}$ & $\mathrm{D}$ & E & \\
\hline$[\mathrm{mm}]$ & \multicolumn{5}{|c|}{$\left[\mathrm{dm}^{3} \cdot \mathrm{s}^{-1} \cdot \mathrm{m}^{-2}\right]$} \\
\hline 2.8 & 0.0000042 & 0.0000094 & 0.0000599 & 0.0000023 & 0.00001899 \\
\hline 5.2 & 0.0002722 & 0.0003028 & 0.0008664 & 0.0001863 & 0.00040691 \\
\hline 9.8 & 0.0005561 & 0.0004879 & 0.0011126 & 0.0002333 & 0.00059750 \\
\hline $\begin{array}{l}\text { Spring snowmelt } \\
\text { (no precipitation) }\end{array}$ & 0.0002553 & 0.0016650 & 0.0068068 & 0.0006048 & 0.00233298 \\
\hline
\end{tabular}

Table 4. Quantity of water from surface runoff at different density of road network and the percentage of this runoff when compared to precipitation in the whole area

\begin{tabular}{|c|c|c|c|}
\hline \multirow{3}{*}{$\begin{array}{c}\text { Precipitation }(3 \mathrm{~h}) \\
{[\mathrm{mm}]}\end{array}$} & \multirow{3}{*}{$\begin{array}{c}\mathrm{q}_{\text {average }}^{\prime} \\
\text { from sections } \\
\mathrm{A}, \mathrm{C}, \mathrm{D} \text { and } \mathrm{E} \\
{\left[\mathrm{dm}^{3} \cdot \mathrm{s}^{-1} \cdot \mathrm{m}^{-2}\right]}\end{array}$} & \multicolumn{2}{|c|}{ Road density $\left[\mathrm{m} \cdot \mathrm{ha}^{-1}\right]$} \\
\hline & & 15 & 25 \\
\hline & & \multicolumn{2}{|c|}{$\begin{array}{l}\text { Water quantity in the runoff lasting } 3 \text { hours }\left[\mathbf{d m}^{3}\right] \\
\text { Surface runoff as \% of precipitation in the whole area of } 100 \text { ha }\end{array}$} \\
\hline 2.8 & 0.00001899 & $\begin{array}{l}923.1 \\
0.03 \%\end{array}$ & $\begin{array}{c}1538.4 \\
0.06 \%\end{array}$ \\
\hline 5.2 & 0.00040691 & $\begin{array}{c}19775.7 \\
0.38 \%\end{array}$ & $\begin{array}{c}32959.5 \\
0.63 \%\end{array}$ \\
\hline 9.8 & 0.00059750 & $\begin{array}{c}29038.4 \\
0.30 \%\end{array}$ & $\begin{array}{c}\mathbf{4 8} \mathbf{3 9 7 . 4} \\
0.49 \%\end{array}$ \\
\hline $\begin{array}{c}\text { Spring snowmelt } \\
\text { (period of } 3 \mathrm{~h} \text {, no precipitation) }\end{array}$ & 0.00233298 & 113382.6 & 188971.1 \\
\hline
\end{tabular}

trench cross the canal of intra-layer runoff. After initial moistening of the surface and increasing precipitation intensity, runoff was observed on all surveyed sections, yet its single intensity is at low level. The section D reacted much stronger. Runoff intensities were presented in the Figures 2 and 3, which were obtained in other measurements with similar precipitation intensity. Runoff intensities obtained here are very similar, with a visible advantage gained in the section D. Both measuring sessions were started on time, when precipitation had already started, yet they showed changed in runoff quantities as the reaction on variations of precipitation and the lack of it (Fig. 3). A 30-minute delay was expressly shown, related to minimum and maximum runoff intensity in relation to minimum and maximum precipitation intensity. The dynamics of this reaction on individual road sections is related to individual features of these sections, which shall be the topic of separate research. Special attention should be paid to the intensity levels as well as the dynamics of changes (at least in the runoff initial phase), considerable impact on ground saturation with water coming from earlier precipitations
(Brodowski \& Rejman 2004). This type of materials and their analyses were included in other works (Gołąb 2011). Calculated runoff intensity levels on ground forest roads, with relatively low precipitation level, oscillating between $0.00001 \div 0.002 \mathrm{dm}^{3} \cdot \mathrm{s}^{-1} \cdot \mathrm{m}^{-2}$, in comparison to the average annual runoffs recorded by Midriak (1990) (Table 1) $-0.00000099 \mathrm{dm}^{3} \cdot \mathrm{s}^{-1} \cdot \mathrm{m}^{-2}$ on the yard or 0.00000055 and $0.00000009 \mathrm{dm}^{3} \cdot \mathrm{s}^{-1} \cdot \mathrm{m}^{-2}$ inside the forest and the data of Słupik (1972): $0.000167 \mathrm{dm}^{3} \cdot \mathrm{s}^{-1} \cdot \mathrm{m}^{-2}$ from the heavy rain inside the forest show the scale of the problem, which is the surface runoff on roads.

When taking these runoff intensities to the forest area of similar, assumed characteristics, the area of 100 ha, it was calculated that with the precipitation level of $2.8 \mathrm{~mm}$ lasting for 3 hours and the road density of $15 \mathrm{~m} \cdot \mathrm{ha}^{-1}$ : surface runoff will be created on roads, with the total value of $923.1 \mathrm{dm}^{3}$. It constitutes the average water consumption of one person for over ninety days (standard consumption level: $100 \mathrm{dm}^{3} \cdot$ day $^{-1} \cdot$ person $\left.^{-1}\right)($ Rozporządzenie Ministra Infrastruktury 2002). For the biggest precipitation level which was measured here of $9.8 \mathrm{~mm}$ and the network 
density of $25 \mathrm{~m} \cdot \mathrm{ha}^{-1}$, runoff was calculated at the level of $48397.4 \mathrm{dm}^{3}$, which constituted 484 times greater daily consumption (demand of one person for almost one and a half of year). For Spring snowmelts, for a 3-hour period without any precipitation and lower road network density, runoff level could obtain the 1134 times of the daily consumption (demand of one person for over three years), yet for the bigger surveyed network density: 1890 times of the daily consumption (demand of one person for over five years). However, these were the results of calculations performed for simulated conditions with many assumptions and averaging, yet their values have considerable meaning. It was supplemented and also in a way mediated the comparison of obtained runoff values with the general water quantity in this precipitation cases in the whole area (Table 4).

Based on the obtained results, the following conclusions have been drawn:

The presence of forest roads in the areas as well as other areas deprived of plants and with changed characteristics of filtration abilities in surface ground layers, decreases retention abilities of these areas.

Soil consolidation in road surfaces causes considerable change of filtration conditions in relation to the natural grounds and occurring surface runoff on roads, even at low precipitation levels, which has its consequences for the quickness of water circulation in nature.

The systems of surface dehydration and their elements applied in road constructions, especially water culverts, can effectively "regain" water from surface runoff, provided that water out flowing from these elements underground surface would be entered with care. A good solution seems to be installing modified absorbent wells just after the outlet of each of these devices.

A great significance for the amount of observed surface runoff from road surfaces has the fact of cutting the canal for intra-layer runoff with the scarp trench. Apart from the drainage effect of sometimes considerable area located above the road, greater erosive losses in road surfaces should be also expected.

The surface runoff level calculated in the simulation show one more time the significance of retention possibilities of the forest mountainous areas. It is especially important in the context of water deficit and the situation of the risk of flooding.

\section{References}

Bochenek W., 2002, Ocena możliwości retencyjnych pokryw glebowo-zwietrzelinowych na stoku pogórskim [Assessment of retention capacity of soil and debris covers on the piedmont slope], Regionalny Monitoring Środowiska Przyrodniczego, nr 3 [Regional Monitoring of Environment, No 3], Kieleckie Towarzystwo Naukowe, Kielce: 103-107.

Brodowski R. \& Rejman J., 2004, Określenie wpływu wilgotności i stanu powierzchni gleby wytworzonej z piasku gliniastego na spływ powierzchniowy i zmyw gleby [Determination of the effect of moisture content and surface conditions of soil developed from loamy sand on the surface runoff and rain-wash], Acta Agrophysica 4(3): 619-624.

Czarniecka A., 1998, Systemy informacji przestrzennej odwzorowanie wybranych elementów ekosystemu za pomocą atrybutowej bazy danych i cyfrowych map wektorowych, praca magisterska, maszynopis [Spatial information systems - mapping of selected elements of the ecosystem using attribute databases and digital vector maps, Master Thesis, manuscript], Wydział Elektrotechniki AGH, Kraków.

Drogi leśne. Poradnik techniczny [Forest roads. Technical Guide], 2006, Wydawnictwo Ośrodek Rozwojowo-Wdrożeniowy Lasów Państw., Bedoń.

Gil E., 1990, Racjonalne użytkowanie ziemi na stokach pod kątem ochrony przeciwpowodziowej i przeciwerozyjnej [Efficient use of soils on the slopes in terms of inundation and erosion control], Problemy Zagospodarowania Ziem Górskich 30: 31-48.

Gołąb J., 2004, Influence of forest slope road on water storage in adjoining soils, EJPAU, Ser. Forestry, www. ejpau.media.pl/series/volume7/issue2.

Gołąb J., 2011, Przechwytywanie wewnątrzgruntowego spływu wody przez wykop leśnej drogi stokowej [Capturing of the intraground flow of water by the forest slope road excavation], Infrastruktura i Ekologia Terenów Wiejskich 7: 179-188.

Gołąb J., Wańczyk R. \& Matusiak B., 2006, Surface runoff from slanting forest roads, Acta Scientiarum Polonorum Silvarum Colendarum Ratio et Industria Lignaria 5 (1): 13-25.

Gradkowski K., 2011, Kontrola spływu powierzchniowego wód z pasów drogowych, cz. 1 [Monitoring of surface runoff from roadways, part 1], Polski Instalator 1/2011: 63-67.

Klimaszewski M. (ed.), 1972, Geomorfologia Polski, tom. 1 Polska Południowa. Góry i wyżyny [Geomorphology of Poland, vol. 1 Southern Poland. Mountains and uplands] PWN, Warszawa.

Kosturkiewicz A. \& Szafrański C., 1983, Spływy powierzchniowe i podpowierzchniowe w bilansie wodnym gleb [Surface and subsurface runoff in the soil water balance], Prace Komisji Nauk Rolniczych i Komisji Nauk Leśnych PTPN 55: 127-144.

Martínez-Zavala L., Jordán López A. \& Bellinfante N., 2008. Seasonal variability of runoff and soil loss on forest road backslopes under simulated rainfall, Catena 74: 73-79. 
Midriak R., 1990, Povrchovy odtok a podne straty vo vysokohorskych ekosystemach, Ved. Pr., VULH 39: 57-78.

Rozporządzenie Ministra Infrastruktury z dnia 14 stycznia 2002 r. w sprawie określenia przeciętnych norm zużycia wody, [Regulation of the Ministry of Infrastructure of January 14, 2002 on the determination of average water consumption standards], Dziennik Ustaw nr 8 z dnia 31 stycznia 2002 r., Poz. 70 [Journal of Laws No. 8 of January 31, 2002, item 70], Warsaw.

Słupik J., 1972, Spływ powierzchniowy na stokach górskich Karpat fliszowych [Surface runoff from slopes of the Flysch Carpathian mountains], Gospodarka Wodna [Water Management] 8: 290-295.

Stachý J., 1987, Atlas hydrologiczny Polski. t I [Hydrological atlas of Poland, vol. 1], Wydawnictwo Geologiczne, Warszawa.
Suliński J. (ed.), 1997, Sprawozdanie z prac wykonanych w I etapie badań "Zbadanie bilansu wodnego świerczyn rasy istebniańskiej", maszynopis [Report on the work completed in the 1st stage of the study "Assessment of the water balance of the Istebna spruce variety", manuscript], Zakład Inżynierii Leśnej, Akademii Rolniczej, Kraków.

Ustawa o lasach, 1991, tekst ujednolicony [Forest Act, 1991, standardized text], Dziennik Ustaw z $2011 \mathrm{nr} 12$ poz. 59 [Journal of Laws No 12 of 2011, item 59], Warszawa.

Wemple B. C. \& Jones J. A., 2003, Runoff production on forest roads in a steep, mountain catchment, Water Resources Research 39(8): 1220, doi:10.1029/2002WR001744. 